\title{
EFEKTIVITAS PENGGUNAAN BIOAKTIF SPONGE UNTUK PENANGGULANGAN BAKTERI Aeromonas sp. PADA NENER BANDENG, Chanos chanos Forskal
}

\author{
Muliani") dan Emma Suryati"'
}

\begin{abstract}
ABSTRAK
Penelitian ini bertujuan untuk mengetahui efektivitas penggunaan bioaktif sponge terhadap penanggulangan penyakit bakteri, Aeromonas sp. pada ikan bandeng (Chanos chanos Forsk.). Percobaan dilakukan di Laboratorium Balai Penelitian Perikanan Pantai, Maros yang meliputi beberapa tahapan kerja yaitu: (1) isolasi dan identifikasi bakteri, Aeromonas sp.; (2) perbanyakan, Aeromonas sp. hasil identifikasi; (3) infeksi Aeromonas sp. sebanyak $10^{5} \mathrm{sel} / \mathrm{mL}$ air, dan pemberian ekstrak sponge Auletta sp., Callyspongia sp., dan Callyspongia pseudoreticulata dengan dosis masing-masing $0,100,200$, dan $300 \mathrm{mg} / \mathrm{L}$ ke dalam wadah pemeliharaan nener bandeng; dan (4) pemantauan perkembangan populasi Aeromonas sp. setelah perendaman dengan ekstrak sponge. Hasil percobaan menunjukkan bahwa penggunaan ekstrak sponge dapat menurunkan populasi Aeromonas sp. baik pada media pemeliharaan maupun pada nener bandeng. Jumlah populasi Aeromonas sp. pada nener bandeng yang diberi ekstrak sponge berbeda nyata $(P<0,05)$ dibanding dengan kontrol namun tidak ada perbedaan yang nyata $(P>0,05)$ antara ketiga jenis sponge pada setiap dosis yang digunakan. Sintasan nener bandeng pada akhir percobaan tidak berbeda nyata $(P>0,05)$ antara semua perlakuan.
\end{abstract}

\section{ABSTRACT: Bioactive effectiveness of sponges to prevention of Aeromonas sp. bacteria on milkfish. By: Muliani and Emma Suryati}

The aim of the experiment was to know the effectiveness of sponge bioactive in prevention of Aeromonas sp. bacterial disease on milkfish (Chanos chanos Forsk.). The experiment was conducted at Research Institute for Coastal Fisheries (RICF) laboratory including several activities i.e.; (1) isolation and identification of bacteria, Aeromonas sp.; (2) propagation of Aeromonas sp. using Nutrient Broth media; (3) spreading of Aeromonas sp. at $10^{5} \mathrm{cell} / \mathrm{mL}$ in water medium and medicinal treatment using sponge bioactive extracts from Auletta sp., Callyspongia sp., and Callyspongia pseudoreticulata with dosages of $0,100,200,300 \mathrm{mg} / \mathrm{L}$ in milkfish water volume culture media $2 \mathrm{~L}$; (4) monitoring of Aeromonas sp. population after treatment by sponges bioactive. The result of the experiment showed that the extract sponges had potencialy to reduce population of Aeromonas sp. both in water medium and in milkfish fry body. The decreasing of Aeromonas sp. population in $2 \mathrm{~L}$ milkfish fry treated by extract sponges was significantly different $(P<0.05)$ with compared to control, eventhough there were not significantly different $(P>0.05)$ among species or dosages. The survival rate of milkfish fry was not significantly different $(P>0.05)$ among the treatments.

KEYWORDS: $\quad$ sponges, bioactive, effectiveness, Aeromonas sp., rnilkfish

\section{PENDAHULUAN}

Kemerosotan usaha budi daya udang windu beberapa tahun terakhir ini menyebabkan banyaknya lahan tambak yang terbengkalai dan tidak termanfaatkan. Di beberapa daerah, tambak yang tidak dapat lagi digunakan untuk budi daya udang dialihfungsikan menjadi tambak bandeng. Diperoleh informasi bahwa bandeng yang dibudidayakan di lahan bekas tambak intensif dapat tumbuh dengan baik dengan memanfaatkan sisa bahan organik di dasar tambak. Dengan semakin meningkatnya pemintaan konsumen akan ikan bandeng menyebabkan usaha budi daya bandeng mengalami perkembangan dari yang tradisional dengan mengandalkan pakan alami menjadi semi maju dengan pemberian pakan tambahan. Hal ini berakibat pula terhadap semakin meningkatnya permintaan akan nener bandeng, sehingga memacu perkembangan hatchery bandeng baik skala besar maupun kecil (skala rumah tangga). Perkembangan suatu sistem usaha perbenihan dan budi daya biasanya akan diikuti oleh sebuah permasalahan terutama yang berkaitan dengan masalah kesehatan organisme peliharaan.

Dalam usaha pembenihan bandeng, kendala yang sering dihadapi adalah terinfeksinya induk bandeng oleh beberapa jenis bakteri antara lain Vibrio sp.

\footnotetext{
Peneliti pada Balai Penelitian Perikanan Pantai, Maros
} 
(Zafran, 1997). Kendala lain yang dihadapi dalam usaha pembenihan bandeng adalah seringnya terjadi kematian larva bandeng secara massal yang disebabkan oleh bakteri Vibrio spp. (Taufik, 1997). Sementara itu pada usaha budi daya bandeng di tambak juga sering ditemukan bandeng yang mengalami kebutaan akibat infeksi bakteri antara lain Vibrio sp. dan Aeromonas sp. Untuk mengantisipasi hal ini perlu diusahakan pencegahannya, baik melalui perbaikan kualitas lingkungan maupun pengelolaan kesehatan ikan bandeng melalui penggunaan obatobatan yang ramah lingkungan.

Kasus yang terjadi pada udang windu diharapkan tidak terjadi pada ikan bandeng di mana ekspor udang windu sering ditolak oleh negara-negara pengimpor karena ditemukan zat-zat antibiotik yang terakumulasi dalam daging udang, selain itu penggunaan antibiotik yang tidak terkontrol akan menimbulkan resistensi pada mikroba patogen (Chythanya, 1999 dan Sze, 2000). Oleh karena itu perlu dicari alternatif lain untuk mengganti antibiotik dengan bahan alami yang ramah lingkungan dan mudah terurai. Bahan alami yang mulai banyak dikaji, antara lain adalah sponge (Oclarit et al., 1994) dan diatomae (Naviner et al., 1999). Sehubungan dengan hal itu, Balai Penelitian Perikanan Pantai, Maros dalam beberapa tahun terakhir ini telah melakukan penelitian untuk menggali potensi bahan alami yang dapat digunakan sebagai alternatif pengganti obat-obatan yang beredar dewasa ini (Suryati, 1993; Suryati \& Hala, 1993; Suryati et al., 1995 dan 1997; Ahmad et al., 1995; dan Muliani et al., 1996 dan 1998; dan Suryati et al., 2000). Sponge merupakan komunitas terumbu karang yang mengandung bahan aktif yang banyak digunakan dalam industri farmasi obatan-obatan untuk hewan dan manusia. Beberapa jenis sponge yang dilaporkan memiliki bioaktif antara lain Hyatella intestinalis mengandung sesterterpen (Karuso et al., 1989); Agelas flabelliformis mengandung metil steroid (Gunasekara et al., 1989); Hipospongia comunis, Spongia officinalis, Ircinia virabilis, Spongia gracilis masing-masing mengandung sesteterpen, terpenoid, variabilin, dan ketosteroid (Madaio et al., 1989); Dysidea avara mengandung varol (Crispino et al., 1989); dan Erylus lendenfeldiserta Dyctionella insica masing-masing mengandung metil steroid glikosida dan ketosteroid (Cimminiello et al., 1989) yang dapat dimanfaatkan dalam bidang farmasi dan pengobatan penyakit pada manusia dan hewan.

Dengan mengacu pada hasil-hasil penelitian yang telah dilakukan oleh beberapa ahli tentang pemanfaatan bioaktif sponge dalam bidang farmasi obat-obatan pada manusia dan hewan, maka Suryati et al. (1995, 1997); Ahmad et al. (1995); Muliani et al. (1996); Muliani et al. (1998a, 1998b) melakukan penapisan bioaktif sponge yang dapat digunakan sebagai bakterisida dan fungisida pada komoditas perikanan pantai. Hasil penelitian Suryati et al. (1995) menunjukkan bahwa sponge dari jenis Callyspongia sp. dan C. pseudoreticulata masing-masing mengandung steroid, sedangkan Auletta sp. mengandung asam fenolat.

Penelitian ini bertujuan untuk mengetahui efektivitas penggunaan bioaktif sponge terhadap penanggulangan bakteri Aeromonas sp. pada nener bandeng.

\section{BAHAN DAN METODE}

Percobaan ini dilakukan di Laboratorium Balai Penelitian Perikanan Pantai, Maros, yang meliputi beberapa tahapan yaitu:

\section{Isolasi dan Identifikasi Aeromonas sp.}

Aeromonas sp. diisolasi dari insang, mata, dan organ dari ikan bandeng dengan cara goresan secara aseptik menggunakan jarum ose, kemudian ditumbunkan dalam media Triptic Soy Agar (TSA) dalam cawan petri selama 48 jam pada suhu $25^{\circ} \mathrm{C}$. Bakteri yang tumbuh pada media tersebut diisolasi dan dimurnikan berdasarkan bentuk, ukuran, dan warna koloni (Hadioetomo, 1993) dan ditumbuhkan pada media TSA miring selama 48 jam pada suhu $25^{\circ} \mathrm{C}$. Setelah itu dilakukan uji karakterisasi secara biokimia (Cowan, 1974; Austine, 1987; Austine, 1991; Austine \& Austine, 1993) menggunakan media $O / F$, TSI agar, SIM, MR-VP, King A, King B, Gelatin, dan Urea Broth. Selanjutnya diidentifikasi sesuai petunjuk Lewis (1973), Austine (1991), Austine \& Austine (1993). Aeromonas sp. yang telah diidentifikasi selanjutnya diremajakan secara berkala untuk selanjutnya dilakukan perbanyakan.

\section{Perbanyakan Aeromonas sp.}

Isolat bakteri Aeromonas sp. yang akan diinfeksikan kepada nener bandeng ditumbuhkan pada media TSA dalam cawan petri, selama 48 jam pada suhu $25^{\circ} \mathrm{C}$. Kemudian diambil sebanyak 15 jarum ose dan ditumbuhkan pada nutrien broth volume $400 \mathrm{~mL}$ selama 48 jam pada suhu $25^{\circ} \mathrm{C}$. Untuk mengetahui kepadatan bakteri dalam nutrien broth, maka diambil $1 \mathrm{~mL}$ dan diencerkan dengan $9 \mathrm{~mL}$ saline solution (pengenceran dilakukan secara bertingkat dari $10^{-1}$, $10^{-2}, 10^{-3}$, dan $10^{-4}$ ) kemudian masing-masing pengenceran diambil $0,1 \mathrm{~mL}$ dan ditumbuhkan pada media TSA dalam cawan petri selama 48 jam pada suhu $25^{\circ} \mathrm{C}$. Selanjutnya dihitung kepadatan Aeromonas sp. yang tumbuh pada media tersebut. Dengan mengetahui jumlah Aeromonas sp. yang tumbuh pada media TSA dalam cawan petri, maka 
kepadatan Aeromonas sp. dalam nutrien broth dapat pula diketahui, sehingga volume suspensi bakteri dalam nutrien broth yang akan diinfeksikan ke dalam media pemeliharaan ikan bandeng dapat diketahui dengan menggunakan rumus pengenceran sebagai berikut:

$\mathrm{N} 1 \mathrm{~V} 1=\mathrm{N} 2 \mathrm{~V} 2$

dengan:

N1 = Kepadatan populasi Aeromonas sp. dalam nutrien broth

V1= Volume suspensi Aeromonas sp. dalam nutrien broth yang dibutuhkan

$\mathrm{N} 2=$ Kepadatan populasi bakteri yang dikehendaki

V2 = Volume media air dalam wadah pemeliharaan ikan bandeng

\section{Infeksi Aeromonas sp. dan Pemberian Ekstrak Sponge ke dalam Wadah Pemeliharaan Nener Bandeng}

Stoples volume $3 \mathrm{~L}$ sebanyak 30 buah digunakan sebagai wadah percobaan. Tiap wadah diisi air laut steril yang bersalinitas 25 ppt sebanyak 2 L. Hewan uji yang digunakan adalah ikan bandeng ukuran gelondongan dengan ukuran panjang $3-5 \mathrm{~cm}$ dan bobot 0,05-0,07 g dengan kepadatan 10 ekor/wadah. Nener bandeng yang telah ditebar dalam stoples diinfeksi dengan bakteri Aeromonas sp. dengan kepadatan $10^{5}$ $\mathrm{sel} / \mathrm{mL}$, setelah 24 jam diberi ekstrak sponge Auletta sp., Callyspongia sp., dan C. pseudoreticulata dengan dosis 100,200 , dan $300 \mathrm{mg} / \mathrm{L}$ dan 0 sebagai kontrol (tanpa ekstrak sponge) secara perendaman. Percobaan dilaksanakan dalam rancangan acak lengkap dengan pola faktorial. Faktor I adalah jenis sponge dan faktor II adalah dosis sponge, di mana masing-masing perlakuan diulang tiga kali.

Untuk mengetahui efektivitas bioaktif sponge terhadap penanggulangan Aeromonas sp., pada nener bandeng, dilakukan pemantauan perkembangan populasi bakteri Aeromonas sp. setiap 24 jam selama 96 jam, sedangkan sintasan ikan bandeng dihitung pada akhir percobaan.

\section{Pemantauan Perkembangan Populasi Aeromonas sp.}

Pemantauan perkembangan populasi Aeromonas sp. dalam media air dilakukan setiap 24 jam, dengan cara mengambil sampel air sebanyak $1 \mathrm{~mL} /$ wadah, kemudian diencerkan dengan $9 \mathrm{~mL}$ larutan garam fisiologis ( $\mathrm{NaCl} 0,85 \%)$. Pengenceran dilakukan secara bertingkat dari $10^{-1}, 10^{-2}$, dan $10^{-3}$; kemudian dari masing-masing pengenceran diambil $0,1 \mathrm{~mL}$ dan ditumbuhkan pada media TSA dalam cawan petri secara duplo, selanjutnya diinkubasi pada suhu $25^{\circ} \mathrm{C}$ selama $48 \mathrm{jam}$. Setelah itu jumlah koloni Aeromonas sp. yang tumbuh pada media tersebut dihitung, sehingga dapat diketahui perkembangan populasi bakteri tersebut selama percobaan. Data yang diperoleh dianalisis dengan bantuan perangkat lunak "Statistik" versi 3.

\section{HASIL DAN BAHASAN}

Hasil percobaan menunjukkan bahwa perkembangan populasi bakteri setiap 24 jam mengalami fluktuasi, baik pada perlakuan yang menggunakan bioaktif sponge dengan dosis yang berbeda maupun pada kontrol (tanpa bioaktif sponge) (Gambar 1). Dari gambar tersebut terlihat bahwa pada 24 jam pertama grafik perkembangan populasi mulai naik dan mencapai puncaknya pada 48 jam dan setelah itu mulai menurun kembali. Persentase penurunan perkembangan populasi Aeromonas sp. pada perlakuan menggunakan ekstrak sponge relatif lebih rendah jika dibanding dengan kontrol, demikian pula ada kecenderungan bahwa semakin tinggi dosis yang digunakan untuk setiap spesies sponge, semakin tinggi persentase penurunan populasi Aeromonas sp. Hal ini menunjukkan bahwa ketiga jenis sponge tersebut dapat menekan perkembangan populasi bakteri Aeromonas sp. dalam media pemeliharaan nener bandeng. Hasil penelitian Ahmad et al. (1995) menunjukkan bahwa jenis sponge yang paling bagus menghambat bakteri Aeromonas sp. antara lain Auletta sp., Callyspongia sp., C. pseudoreticulata, dan Halicondria cartilagena. Namun demikian hasil uji statistik menunjukkan bahwa penggunaan ekstrak ketiga spesies sponge dalam percobaan ini tidak memperlihatkan perbedaan yang nyata $(P>0,05)$ terhadap penurunan populasi Aeromonas sp. dalam media pemeliharaan nener bandeng, begitu pula dosis 100, 200, dan $300 \mathrm{mg} / \mathrm{L}$ untuk semua jenis sponge. Hal ini mungkin disebabkan perbedaan dosis ekstrak sponge yang digunakan terlalu rendah.

Hasil uji statistik terhadap populasi bakteri setiap gram nener bandeng memperlihatkan perbedaan yang nyata $(P<0,05)$, antara perlakuan yang menggunakan bioaktif sponge, Auletta sp., Callyspongia sp., dan $C$. pseudoreticulata dengan kontrol (tanpa bioaktif sponge), tetapi tidak ada perbedaan yang nyata antara dosis yang digunakan pada ketiga jenis sponge tersebut (Tabel 1). Dari Tabel 1 terlihat bahwa pada semua tingkatan dosis Auletta sp. dan C. pseudoreticulata mampu menekan perkembangan populasi bakteri Aeromonas sp. sekitar $10^{7} \mathrm{CFU} / \mathrm{mL}$ (kontrol) menjadi $10^{4} \mathrm{CFUImL}$ atau sebesar $37,5 \%$ dan Callyspongia sp. sekitar $10^{7} \mathrm{CFU} / \mathrm{mL}$ menjadi $10^{5}$ $\mathrm{CFU} / \mathrm{mL}$ atau sebesar $25,0 \%$. Dengan demikian ketiga jenis sponge yang digunakan efektif sebagai bakterisida khususnya untuk menekan kolonisasi 
A. Auletta sp.

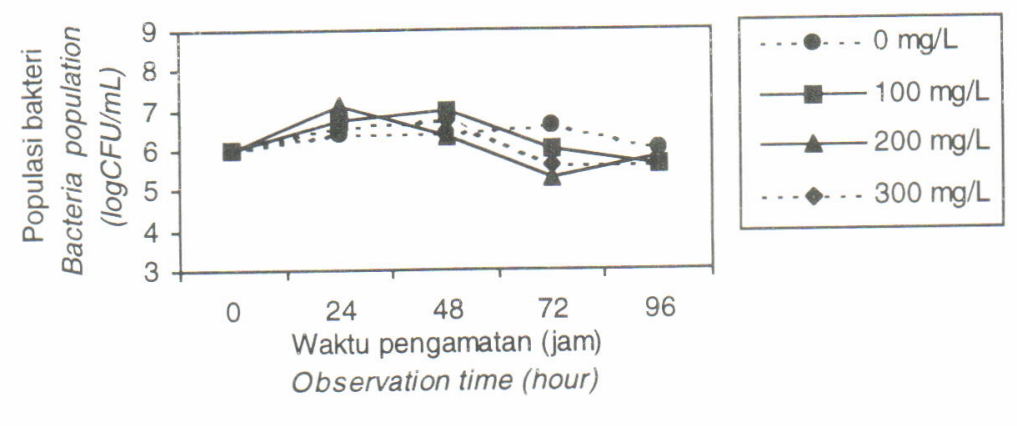

B. Callyspongia sp.

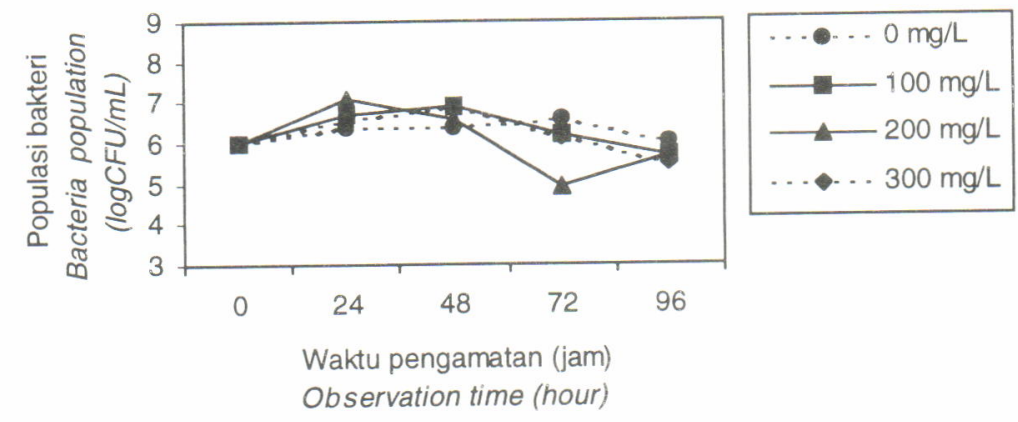

C. Callyspongia pseudoreticulata

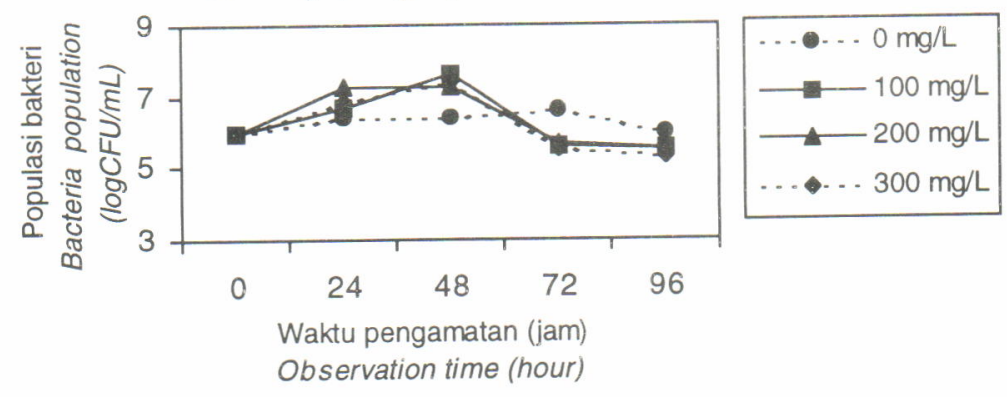

Gambar 1. Populasi Aeromonas sp. selama 96 jam perendaman dengan menggunakan bioaktif sponge Figure 1. Population of Aeromonas sp. during 96 hours treated by bioactive of sponges

Aeromonas sp. pada ikan bandeng. Menurut Salle (1961) bakterisida pada umumnya menghambat pertumbuhan bakteri dengan cara mengiritasi dinding sel, menggumpalkan protein bakteri serta terjadi hidrolisis dan difusi cairan sel yang disebabkan perbedaan tekanan osmose.

Tidak adanya perbedaan daya hambat yang berarti antara semua dosis yang digunakan untuk semua jenis sponge diduga karena konsentrasi kepekatan dari ekstrak sponge masih rendah, sehingga perlu dilakukan penelitian dengan cara meningkatkan konsentrasi kepekatan bioaktif sponge.

Hasil uji statistik terhadap sintasan hidup nener bandeng menunjukkan bahwa jenis maupun dosis ekstrak sponge yang digunakan tidak memperlihat- kan perbedaan yang nyata $(P>0,05)($ Tabel 2$)$. Hal ini menunjukkan bahwa konsentrasi bakteri Aeromonas sp. yang digunakan belum mencapai tahap yang mematikan, demikian pula dosis bioaktif sponge yang digunakan masih berada di bawah ambang yang mematikan nener bandeng, hal ini terlihat pada perlakuan tanpa penggunaan bioaktif sponge (kontrol) perkembangan populasi bakteri Aeromonas sp. mencapai $10^{7} \mathrm{CFU} / \mathrm{mL}$ namun tidak menimbulkan kematian pada nener bandeng sampai pada akhir penelitian (Tabel 2).

Adanya kematian nener bandeng pada dosis 100 $\mathrm{mg} / \mathrm{L}$ (pada penggunaan Auletta sp. dan Callyspongia pseudoreticulata) dengan dosis 100 dan $200 \mathrm{mg} / \mathrm{L}$ (Callyspongia sp.) yang terlihat pada Tabel 2 diduga 
kepadatan Aeromonas sp. dalam nutrien broth dapat pula diketahui, sehingga volume suspensi bakteri dalam nutrien broth yang akan diinfeksikan ke dalam media pemeliharaan ikan bandeng dapat diketahui dengan menggunakan rumus pengenceran sebagai berikut:

$\mathrm{N} 1 \mathrm{~V} 1=\mathrm{N} 2 \mathrm{~V} 2$

dengan:

N1 = Kepadatan populasi Aeromonas sp. dalam nutrien broth

V1 = Volume suspensi Aeromonas sp. dalam nutrien broth yang dibutuhkan

$\mathrm{N} 2=$ Kepadatan populasi bakteri yang dikehendaki

$\mathrm{V} 2=$ Volume media air dalam wadah pemeliharaan ikan bandeng

\section{Infeksi Aeromonas sp. dan Pemberian Ekstrak Sponge ke dalam Wadah Pemeliharaan Nener Bandeng}

Stoples volume $3 \mathrm{~L}$ sebanyak 30 buah digunakan sebagai wadah percobaan. Tiap wadah diisi air laut steril yang bersalinitas 25 ppt sebanyak $2 \mathrm{~L}$. Hewan uji yang digunakan adalah ikan bandeng ukuran gelondongan dengan ukuran panjang $3-5 \mathrm{~cm}$ dan bobot 0,05-0,07 g dengan kepadatan 10 ekor/wadah. Nener bandeng yang telah ditebar dalam stoples diinfeksi dengan bakteri Aeromonas sp. dengan kepadatan $10^{5}$ $\mathrm{sel} / \mathrm{mL}$, setelah 24 jam diberi ekstrak sponge Auletta sp., Callyspongia sp., dan C. pseudoreticulata dengan dosis 100,200 , dan $300 \mathrm{mg} / \mathrm{L}$ dan 0 sebagai kontrol (tanpa ekstrak sponge) secara perendaman. Percobaan dilaksanakan dalam rancangan acak lengkap dengan pola faktorial. Faktor I adalah jenis sponge dan faktor II adalah dosis sponge, di mana masing-masing perlakuan diulang tiga kali.

Untuk mengetahui efektivitas bioaktif sponge terhadap penanggulangan Aeromonas sp., pada nener bandeng, dilakukan pemantauan perkembangan populasi bakteri Aeromonas sp. setiap 24 jam selama 96 jam, sedangkan sintasan ikan bandeng dihitung pada akhir percobaan.

\section{Pemantauan Perkembangan Populasi Aeromonas sp.}

Pemantauan perkembangan populasi Aeromonas sp. dalam media air dilakukan setiap 24 jam, dengan cara mengambil sampel air sebanyak $1 \mathrm{~mL} /$ wadah, kemudian diencerkan dengan $9 \mathrm{~mL}$ larutan garam fisiologis $(\mathrm{NaCl} 0,85 \%)$. Pengenceran dilakukan secara bertingkat dari $10^{-1}, 10^{-2}$, dan $10^{-3}$; kemudian dari masing-masing pengenceran diambil $0,1 \mathrm{~mL}$ dan ditumbuhkan pada media TSA dalam cawan petri secara duplo, selanjutnya diinkubasi pada suhu $25^{\circ} \mathrm{C}$ selama 48 jam. Setelah itu jumlah koloni Aeromonas sp. yang tumbuh pada media tersebut dihitung, sehingga dapat diketahui perkembangan populasi bakteri tersebut selama percobaan. Data yang diperoleh dianalisis dengan bantuan perangkat lunak "Statistik" versi 3.

\section{HASIL DAN BAHASAN}

Hasil percobaan menunjukkan bahwa perkembangan populasi bakteri setiap 24 jam mengalami fluktuasi, baik pada perlakuan yang menggunakan bioaktif sponge dengan dosis yang berbeda maupun pada kontrol (tanpa bioaktif sponge) (Gambar 1). Dari gambar tersebut terlihat bahwa pada 24 jam pertama grafik perkembangan populasi mulai naik dan mencapai puncaknya pada 48 jam dan setelah itu mulai menurun kembali. Persentase penurunan perkembangan populasi Aeromonas sp. pada perlakuan menggunakan ekstrak sponge relatif lebih rendah jika dibanding dengan kontrol, demikian pula ada kecenderungan bahwa semakin tinggi dosis yang digunakan untuk setiap spesies sponge, semakin tinggi persentase penurunan populasi Aeromonas sp. Hal ini menunjukkan bahwa ketiga jenis sponge tersebut dapat menekan perkembangan populasi bakteri Aeromonas sp. dalam media pemeliharaan nener bandeng. Hasil penelitian Ahmad et al. (1995) menunjukkan bahwa jenis sponge yang paling bagus menghambat bakteri Aeromonas sp. antara lain Auletta sp., Callyspongia sp., C. pseudoreticulata, dan Halicondria cartilagena. Namun demikian hasil uji statistik menunjukkan bahwa penggunaan ekstrak ketiga spesies sponge dalam percobaan ini tidak memperlihatkan perbedaan yang nyata $(P>0,05)$ terhadap penurunan populasi Aeromonas sp. dalam media pemeliharaan nener bandeng, begitu pula dosis 100, 200, dan $300 \mathrm{mg} / \mathrm{L}$ untuk semua jenis sponge. Hal ini mungkin disebabkan perbedaan dosis ekstrak sponge yang digunakan terlalu rendah.

Hasil uji statistik terhadap populasi bakteri setiap gram nener bandeng memperlihatkan perbedaan yang nyata $(P<0,05)$, antara perlakuan yang menggunakan bioaktif sponge, Auletta sp., Callyspongia sp., dan C. pseudoreticulata dengan kontrol (tanpa bioaktif sponge), tetapi tidak ada perbedaan yang nyata antara dosis yang digunakan pada ketiga jenis sponge tersebut (Tabel 1). Dari Tabel 1 terlihat bahwa pada semua tingkatan dosis Auletta sp. dan $C$. pseudoreticulata mampu menekan perkembangan populasi bakteri Aeromonas sp. sekitar $10^{7} \mathrm{CFU} / \mathrm{mL}$ (kontrol) menjadi $10^{4} \mathrm{CFU} / \mathrm{mL}$ atau sebesar $37,5 \%$ dan Callyspongia sp. sekitar $10^{7} \mathrm{CFU} / \mathrm{mL}$ menjadi $10^{5}$ $\mathrm{CFU} / \mathrm{mL}$ atau sebesar 25,0\%. Dengan demikian ketiga jenis sponge yang digunakan efektif sebagai bakterisida khususnya untuk menekan kolonisasi 
A. Auletta sp.

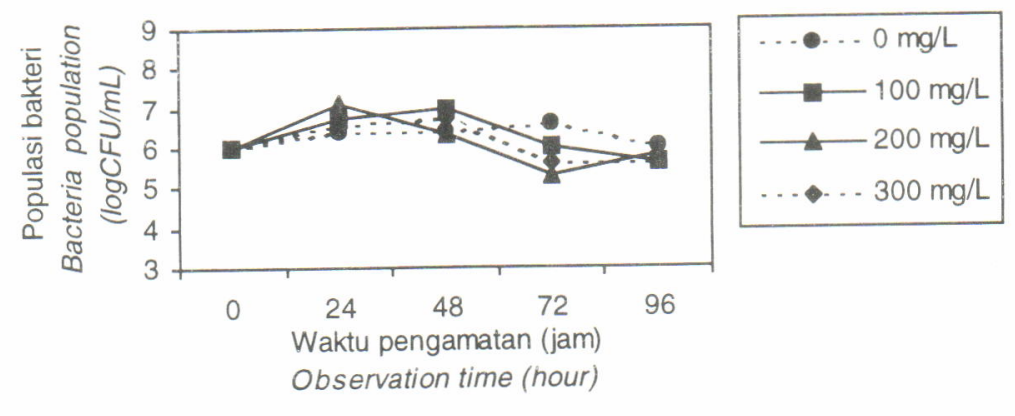

B. Callyspongia sp.

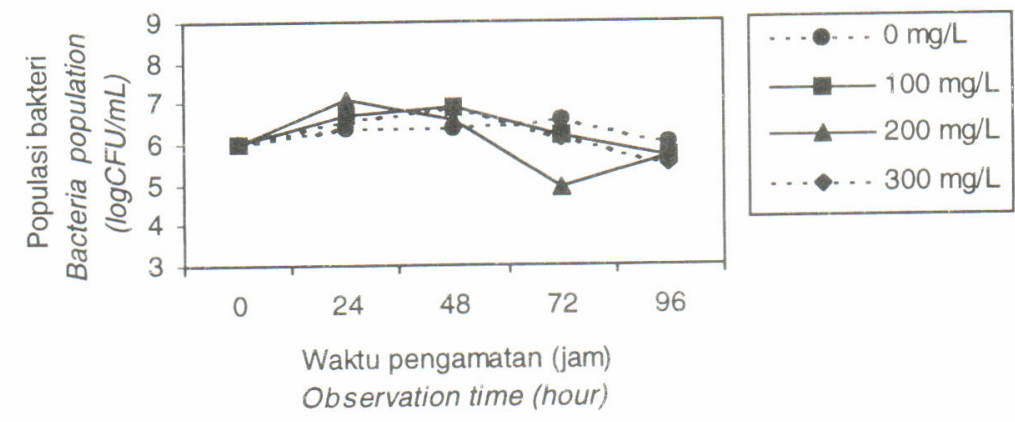

C. Callyspongia pseudoreticulata

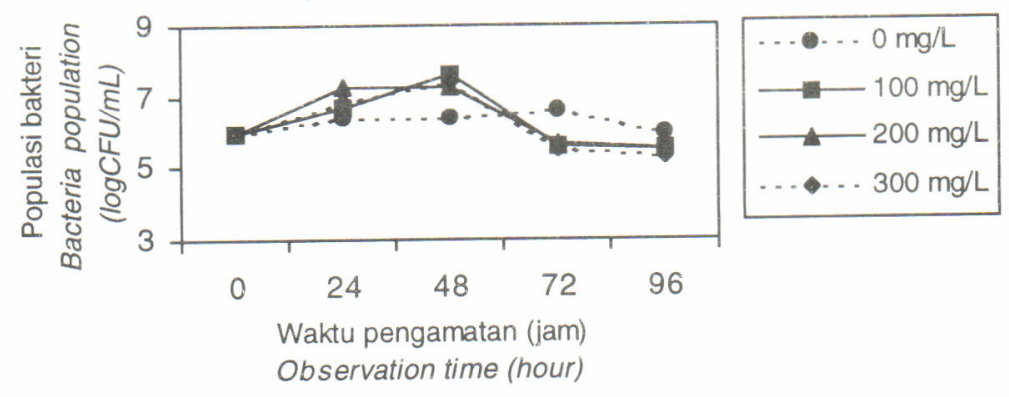

Gambar 1. Populasi Aeromonas sp. selama 96 jam perendaman dengan menggunakan bioaktif sponge Figure 1. Population of Aeromonas sp. during 96 hours treated by bioactive of sponges

Aeromonas sp. pada ikan bandeng. Menurut Salle (1961) bakterisida pada umumnya menghambat pertumbuhan bakteri dengan cara mengiritasi dinding sel, menggumpalkan protein bakteri serta terjadi hidrolisis dan difusi cairan sel yang disebabkan perbedaan tekanan osmose.

Tidak adanya perbedaan daya hambat yang berarti antara semua dosis yang digunakan untuk semua jenis sponge diduga karena konsentrasi kepekatan dari ekstrak sponge masih rendah, sehingga perlu dilakukan penelitian dengan cara meningkatkan konsentrasi kepekatan bioaktif sponge.

Hasil uji statistik terhadap sintasan hidup nener bandeng menunjukkan bahwa jenis maupun dosis ekstrak sponge yang digunakan tidak memperlihat- kan perbedaan yang nyata $(P>0,05)($ Tabel 2$)$. Hal ini menunjukkan bahwa konsentrasi bakteri Aeromonas sp. yang digunakan belum mencapai tahap yang mematikan, demikian pula dosis bioaktif sponge yang digunakan masih berada di bawah ambang yang mematikan nener bandeng, hal ini terlihat pada perlakuan tanpa penggunaan bioaktif sponge (kontrol) perkembangan populasi bakteri Aeromonas sp. mencapai $10^{7} \mathrm{CFU} / \mathrm{mL}$ namun tidak menimbulkan kematian pada nener bandeng sampai pada akhir penelitian (Tabel 2).

Adanya kematian nener bandeng pada dosis 100 mg/L (pada penggunaan Auletta sp. dan Callyspongia pseudoreticulata) dengan dosis 100 dan $200 \mathrm{mg} / \mathrm{L}$ (Callyspongia sp.) yang terlihat pada Tabel 2 diduga 
Tabel 1. Populasi bakteri Aeromonas sp. (CFU/g) nener bandeng setelah 96 jam perendaman dengan bioaktif sponge

Table 1. Population of Aeromonas sp. bacterial (CFU/g) of milk fish fry after 96 hours treated by bioactive of sponges

\begin{tabular}{cccc}
\hline \multirow{2}{*}{ Dosis (Dosage) (mg/L) } & \multicolumn{3}{c}{ Jenis sponge (Species of sponges) } \\
\cline { 2 - 4 } & Auletta sp. & Callyspongia sp. & C. pseudoreticulata \\
\hline 0 & $1.1 \times 10^{7 \mathrm{a}}$ & $1.1 \times 10^{7 \mathrm{a}}$ & $1.0 \times 10^{7 \mathrm{a}}$ \\
100 & $1.2 \times 10^{4 \mathrm{~b}}$ & $1.4 \times 10^{5 \mathrm{~b}}$ & $2.7 \times 10^{4 \mathrm{~b}}$ \\
200 & $1.9 \times 10^{4 \mathrm{~b}}$ & $1.7 \times 10^{5 \mathrm{~b}}$ & $2.3 \times 10^{4 \mathrm{~b}}$ \\
300 & $6.7 \times 10^{4 \mathrm{~b}}$ & $3.7 \times 10^{5 \mathrm{~b}}$ & $3.1 \times 10^{4 \mathrm{~b}}$ \\
\hline
\end{tabular}

Note: Huruf yang sama pada baris dan kolom yang sama menunjukkan perbedaan yang tidak nyata $(P>0,05)$ The similiar superscripts in one column and one line is not significantlly different $(P>0.05)$

Tabel 2. Sintasan nener bandeng (\%) setelah 96 perendaman bioaktif sponge Table 2. Survival rate (\%) of milk fish fry after 96 hours treated by bioactifve of sponges

\begin{tabular}{cccc}
\hline \multirow{2}{*}{ Dosis (Dosage) $(\mathrm{mg} / \mathrm{L})$} & \multicolumn{3}{c}{ Jenis sponge (Species of sponges) } \\
\cline { 2 - 4 } & Auletta sp. & Callyspongia sp. & C. pseudoreticulata \\
\hline 0 & $100.0^{\mathrm{a}}$ & $100.0^{\mathrm{a}}$ & $100.0^{\mathrm{a}}$ \\
100 & $93.3^{\mathrm{a}}$ & $98.3^{\mathrm{a}}$ & $98.3^{\mathrm{a}}$ \\
200 & $100.0^{\mathrm{a}}$ & $93.3^{\mathrm{a}}$ & $100.0^{\mathrm{a}}$ \\
300 & $100.0^{\mathrm{a}}$ & $100.3^{\mathrm{a}}$ & $100.0^{\mathrm{a}}$ \\
\hline
\end{tabular}

Note: Huruf yang sama pada baris dan kolom yang sama menunjukkan perbedaan yang tidak nyata $(P>0,05)$ The similiar superscripts in the same column and row are not significantlly different $(P>0.05)$

disebabkan kerusakan fisik dari nener bandeng itu sendiri, yang disebabkan oleh kesalahan teknis dalam penanganan selama percobaan berlangsung.

\section{KESIMPULAN}

- Penggunaan bioaktif sponge (Auletta sp., Callyspongia sp., dan C. pseudoreticulata) mampu menurunkan kepadatan populasi bakteri Aeromonas sp. pada media pemeliharaan nener bandeng.

- Ketiga jenis sponge yang digunakan efektif untuk menekan bakteri Aeromonas sp. pada nener bandeng, meskipun dosis yang digunakan untuk masing-masing sponge masih perlu dilakukan kajian dengan cara peningkatan dosis yang digunakan.

\section{UCAPAN TERIMA KASIH}

Penulis mengucapkan banyak terima kasih kepada analis (Nurjanna dan Rifka Pasande) yang telah membantu terlaksananya penelitian ini.

\section{DAFTAR PUSTAKA}

Ahmad, T., E. Suryati, dan Muliani. 1995. Screening sponges for bactericide to be used in shrimp cul- ture. Indonesian Fisheries Research Journall (1): 110.

Austine, B. 1987. Marine Microbiology. Cambridge University Press. Cambridge. 222 pp.

Austine, B. 1991. Methods in Aquatic Bacteriology. John Wiley and Sons. Chichester. New York. Brisbane. Toronto. Singapore. $425 \mathrm{pp}$.

Austin, B. and D.A. Austin. 1993. Bacterial Fish Pathogens. Disease in Farmed and Wild Fish. Second edition. New York. London. Toronto. Sydney. Tokyo. Singapore. 384 pp.

Chythanya R, Nayak DK, Venugopal MN. 1999. Antibiotic resistance in aquaculture. News from around the world. Infofish International. 6: 30-32.

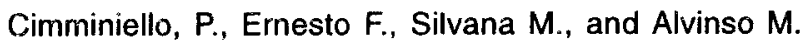
1989. A Novel conyugated ketosteroid from the marine sponge Dyctionella incisa. J. of Natural Product. 52 (6): 1331-1333.

Crispino, A., Deguillo, Des Rosa, and G. Strazullo. 1989. A new bioactive derivation of avarol from the marine sponge Dysidea avara. J. of Natural Product. 52 (6): 646.648.

Cowan, S. T. 1974. Cowan and Steel's Manual for the identification of Medical Bacteria, $2^{\text {nd }}$ edition. Cambridge University Press. Cambridge.

Gunasekara, S.P., S. Crarnck, and R. Longlei. 1989. Immunosuppre sive compounds from a deep water 